\title{
IAMJ
}

INTERNATIONAL

AYURVEDIC

MEDICAL JOURNAL

\section{EFFECTIVE MANAGEMENT OF VATALA YONIVYAPDA W.S.R ENDOMETRIOSIS BY AYURVEDA: A CASE REPORT}

\author{
Poonam Kumari $^{1^{*}}$, Poonam Choudhary ${ }^{2 *}$, Hetal H. Dave ${ }^{3 *}$, Sonu $^{4 *}$
}

${ }^{1}$ MS Scholar, Final year, Department of Prasuti-Stri Roga, National Institute of Ayurveda, deemed to be University Jaipur, Rajasthan, India

${ }^{2}$ Assistant Professor, Department of Prasuti-Stri Roga, National Institute of Ayurveda, deemed to be University Jaipur, Rajasthan, India

${ }^{3}$ Associate Professor, Department of Prasuti-Stri Roga, deemed to be University National Institute of Ayurveda, Jaipur, Rajasthan, India

${ }^{4}$ Assistant Professor, Department of Prasuti-Stri Roga, National Institute of Ayurveda, deemed to be University Jaipur, Rajasthan, India

Corresponding Author: azadpoo77@gmail.com

\section{https://doi.org/10.46607/iamj5509092021}

(Published Online: September 2021)

Open Access

(C) International Ayurvedic Medical Journal, India 2021

Article Received: 31/08//2021 - Peer Reviewed: 06/09/2021 - Accepted for Publication: 07/09/2021

\section{Check for updates}

\section{ABSTRACT}

Background: A married Hindu female patient of 44 years of age visited OPD of National Institute of Ayurveda, deemed to be university, Jaipur on 30 December 2020. She was having chief complaint of extreme and unbearable pain starting 2-3 days before menstruation and continuing in her menstruation also.

Methodology: On reviewing her laboratory investigations (USG) she was diagnosed with Endometriosis. On detailed history, Dosha assessment was done based on the clinical features and mainly Vata Dosha was found to be vitiated in the present patient. Considering this, she was diagnosed with Vatala Yonivyapada, and treatment was given to her based on the line of treatment explained for Vatala Yonivyapada in classics.

Result: Patients showed complete relief in extreme pain during menstruation in the very $1^{\text {st }}$ first cycle following treatment and she is having complete relief in pain to date. 
Keywords: Vatala Yonivyapada, Endometriosis, Dysmenorrhea

\section{INTRODUCTION}

Physiological aspect of Artava is of great concern that has been mentioned in detail by different Acharya in classics. Acharya has described the duration, interval of Artava. Along with the above, Acharya has also mentioned the characteristics of Shudha Artava in classics. Artava is considered to be Shudha, if it occurs at interval of one month for 5 days duration and is not associated with any type of pain or burning sensation, devoid of unctuous, neither excessive nor scanty ${ }^{1}$. Acharya Bhavamishra has further mentioned that the absence of pain and burning sensation during menstruation is related to the Prakruta Vata Dosha ${ }^{2}$. Variation of Artava from the above physiological aspects is abnormal and has been explained by Acharya in detail under the heading of Yonivyapada in Samhitas. Vatala Yonivyapada has been explained by Acharyas. Acharya Charaka mentioned several general symptoms in this particular entity along with which painful menstruation has been mentioned ${ }^{3}$. Acharya Bhavamishra mentioned excessive pain in its symptoms. ${ }^{4}$ So considering the complaints told by patient's present case was considered the case of Vatala Yonivyapada. On considering in modern medical science present case be considered of Endometriosis as the patient had her USG done that was suggestive of Endometriosis. Endometriosis is a clinical entity whereby the functioning endometrium i.e. glands and stroma are present in sites other than uterine mucosa. Its prevalence is about $10 \%$ and has been increasing during the last couple of decades 5 . According to WHO, Endometriosis affects roughly $10 \%$ (190 million) of reproductive age women and girls globally ${ }^{6}$. Endometriosis Society of India has estimated that 25 million Indian women suffer from this condition ${ }^{7}$. If we focus on the clinical features of pelvic endometriosis explained by modern medical science then dysmenorrhea is found to contribute for the majority of cases i.e. 70\% followed by infertility (40-60\%), abnormal menstruation (20\%) and dyspareunia for $(20-40 \%)$ of cases $^{8}$. Considering the complaint of the subject of the present case study, she was having severe and unbearable progressive pain starting 3-4 before menstruation and getting worsened during menstruation which is one of the peculiar clinical features of endometriosis. So based on the different clinical features explained in the Ayurveda text this case can be considered of Vatala Yonivyapada and can be co-related with the pelvic endometriosis kind of pathological entity of modern medical science. So, in this article, an attempt has been made to analyse the effect of Ayurvedic treatment in the case of pelvic endometriosis.

AIM: To understand the Dosha and symptom specific Ayurvedic drugs and Yogas in the management of Vatala Yonivyapada w.s.r. to Pelvic Endometriosis.

\section{MATERIALS AND METHODS: CASE REPORT:}

A married Hindu female patient of age 44 years visited OPD of Prasuti Tantra evum Stri Roga of NIA, deemed to be university, Jaipur on 30 December 2020. She was having a chief complaint of severe and unbearable pain starting 3-4 days before menstruation which use to get worsened during menstruation. She was suffering from this problem for about 12-13 years for which she has consulted Allopathic gynaecologists but didn't get any relief. She also had taken homoeopathic consultations for the same problem but didn't get any relief. So, she came to OPD of NIA hospital in the hope of cure and better management.

Table 1: Menstrual Histor

\begin{tabular}{|l|l|}
\hline Age of Menarche & 13 years of age \\
\hline L.M.P & 21.12 .2020 \\
\hline Pattern & Regular \\
\hline Duration & 4- 5 days \\
\hline
\end{tabular}




\begin{tabular}{|l|l|}
\hline Interval & 23-24 days \\
\hline Clots & Absent \\
\hline Colour & Dark Reddish \\
\hline Flow & Normal \\
\hline Pain & $\begin{array}{l}\text { Severe (Visual Analog Scale was used to assess pain and the patient marked } 10 \text { number for the pain } \\
\text { experienced by her during menstruation) }\end{array}$ \\
\hline Pad History & $\mathrm{D}_{1:} 1$ Pad \\
& $\mathrm{D}_{2}: 2-3$ Pads \\
& $\mathrm{D}_{3:} 2$ Pads \\
& $\mathrm{D}_{4}-\mathrm{D}_{5:} 1$ Pad \\
\hline
\end{tabular}

Married Life: 22 years

Active Married Life: 22 years

Obstetric History: $\mathbf{G}_{\mathbf{2}} \mathbf{P}_{\mathbf{2}} \mathbf{L}_{\mathbf{2}} \mathbf{A}_{\mathbf{0}}$

$\mathbf{G}_{1:}$ FTND Female Child, 21 years ago, delivered at the hospital

$\mathbf{G}_{2:}$ FTND Male Child, 17 years ago, delivered at the hospital

Contraceptive History: Nil

Past Medical History: History of taking allopathic and homoeopathic medicines for several years for the same issue. Presently she was taking Meftal Spas and Combiflame during menstruation to relieve pain which was also not effective at all.

Past Surgical History: Nil

Family History: Not Significant

Personal History:

Diet: Vegetarian

Appetite: Normal

Sleep: Sound Sleep
Bowel habits: Irregular (Constipated sometimes)

Micturition: Clear

Allergic History: Not any

Examination:

Physical examination:

Body Built: Moderate

Height: 5'4',

Weight: $62 \mathrm{~kg}$

BMI: $23.5 \mathrm{~kg} / \mathrm{m}^{2}$

Pulse: $80 / \mathrm{min}$

BP: $120 / 70 \mathrm{mmHg}$

RR: $18 / \mathrm{min}$

Systemic Examination:

Respiratory System:

Inspection: $\mathrm{B} / \mathrm{L}$ chest symmetrical

Auscultation: Air entry equal on both sides

Cardiovascular System:

Auscultation: Normal Heart Sound

Central Nervous System:

Orientation: The patient was well oriented

Table 2: Dashavidha Pariksha

\begin{tabular}{|l|l|}
\hline Prakruti & Vata-Pittaja \\
\hline Vikruti & Vataja \\
\hline Sara & Asthisara \\
\hline Samhana & Madhyama \\
\hline Pramana & Madhyama \\
\hline Satmaya & Saravarasa Satmaya \\
\hline Satva & Madhyama \\
\hline Ahara Shakti & Abhyavahrana Shakti: Madhyama \\
\hline & Jarana Shakti: Madhyama \\
\hline Vyayama Shakti & Madhyama \\
\hline Vaya & Adhiroodha \\
\hline
\end{tabular}




\section{Investigations (USG):}

The patient was having her USG done on 9 November 2019 which was suggestive of Endometriosis.

Diagnosis (according to Ayurvedic Science): Vatala Yonivyapada

Diagnosis (according to Modern Medical Science): Secondary Dysmenorrhea due to Pelvic Endometriosis Line of Treatment: Line of treatment is very important before laying the actual treatment of disease.
The general line of treatment as well as a specific line of treatment according to Doshas and symptoms was provided to the patient. She was asked to avoid all the Vatavardhaka Ahara considering the severity of Vata Dushti. The main line of treatment was laid according to Dosha and Lakshana specificity, which was mainly being Vatahshamaka, Anulomaka Vedanasthapana and Shoolahara.

Treatment Given: The patient was treated with the following medications:

Table 3: Detailed Posology of medications given to the patient:

\begin{tabular}{|c|c|c|c|c|c|}
\hline Sr. No. & Aushdha Name & Dose & Dose Form & Frequency & Time of administration \\
\hline 1. & $\begin{array}{l}\text { Rasna Moola } \\
+ \\
\text { Eranda Moola } \\
+ \\
\text { Devadaru Twaka }\end{array}$ & 3-gram powder of each & Kwatha & $40 \mathrm{ml} \mathrm{BD}$ & Before meal \\
\hline 2. & $\begin{array}{l}\text { Haritki Churna } \\
+ \\
\text { Arjuna Churna } \\
+ \\
\text { Amalaki Chruna }\end{array}$ & $\begin{array}{l}3 \mathrm{gm} \\
2 \mathrm{gm} \\
2 \mathrm{gm}\end{array}$ & Powder & $\mathrm{BD}$ & Before meal \\
\hline 3. & Saraswatarishta & $\begin{array}{l}20 \mathrm{ml} \text { with an equal } \\
\text { amount of water }\end{array}$ & Arishta & $\mathrm{BD}$ & After meal \\
\hline 4. & $\begin{array}{l}\text { Panchtikta Ghrita Gug- } \\
\text { gulu }\end{array}$ & 2 Tablets & Tablet & $\mathrm{BD}$ & After meal \\
\hline 5. & $\begin{array}{l}\text { Tarunikusumakara } \\
\text { Churna }\end{array}$ & $4 \mathrm{gm}$ & Powder & HS & After meal \\
\hline
\end{tabular}

\section{OBSERVATIONS \& RESULT:}

The patient was followed up following the first menstrual cycle after initiation of medications following observations were laid down on the chief complaint of the patient:

Table 4:

\begin{tabular}{|l|l|}
\hline Pain score before treatment (based on Visual Analog Scale) & Pain score before treatment (based on Visual Analog Scale) \\
\hline 10 & 0 (Following $1^{\text {st }}$ Menstrual cycle) \\
\hline & 0 (Following $2^{\text {nd }}$ Menstrual cycle) \\
\hline
\end{tabular}

Based on the above observation, the result was drawn that the patient got complete relief from severe pain to no pain during menstruation following the very $1^{\text {st }}$ menstrual cycle which was continued (no pain during menstruation) to date.

\section{DISCUSSION}

1. Rasna Moola Kwatha was selected for this patient possess many properties that helped to breakdown the pathogenesis like Rasna has been mentioned to be supreme among the Vatashamaka Dravya ${ }^{9}$ which is the main causative factor in this case. 
Rasna is used mostly for Vedanasthapana or Shoolaprashamana ${ }^{10}$ which was the main complaint of the patient in this patient. Shoolaprashamana and Vedanasthaphana properties have been established of Rasna which helped in relieving pain by pacifying the Vata ${ }^{11}$. Rasna has also been experimented with to have analgesic and antispasmodic pharmacological properties ${ }^{12}$ which have worked on excessive pain in this patient by inhibiting the action of Prostaglandins and Thromboxane that has been stated to be the main culprit for dysmenorrhea in the ectopic endometrium or endometriosis.

Erandamoola was also given in Kwatha form along with Rasna due to its various properties like it is one of best among Vatashamaka Dravya due to which it possesses pain-relieving (Vedana Sthapaka ${ }^{13}$ properties and hence the breakdown of pathogenesis in this case. Amadoshahara along with Vedanasthapana property of Eranda might have led to the destruction of Ama which is the foremost cause of almost all diseases leading to pacifying Dosha specifically Vata and hence Vedana during menstruation caused due to Vata. Also, Eranda has been indicated in specifically VataVikara, in various types of Shoola specifically Bastishoola $^{14}$ which is a place of Apana Vata that is having great concern with the physiology of menstruation. Thus, Vatahara and Bastishoolahara property has combinedly worked on pacifying Vata and Shoola, hence destructing pathogenesis. Spasmolytic property ${ }^{15}$ has been experimented on Eranda which might have led to relieve the spasm of smooth muscles of the uterus thus inhibiting the action of agents causing dysmenorrhea. Depurative action ${ }^{16}$ of Ricinus Communis has been mentioned which have led to purification or Shodana of the whole body thus removing toxins to balance Dosha and, hence destructing the pathogenesis.

Devadaru administered along with the above two has properties of Vatashamana due to its Snigdha and Ushna Guna leading to pacify pain hence breakdown of pathogenesis. ${ }^{17}$ Anulomana along with Vedanasthapana property ${ }^{18}$ of Devadru have led to regulate the physiologic Gati of Vata i.e. Anuloma Gati thus leading to the physiological functioning of Vata and thus pacifying the pain during menstruation caused due to ectopic endometrium. Analgesic, as well as antispasmodic property, has been experimented of Devdaru $^{19}$ which has led to pacify dysmenorrhea by inhibiting the release of Prostaglandins and relieving muscle spasms of the uterus.

2. Haritki, Arjuna and Amalaki together has been mentioned in Bhaishajya Ratnavali under $R a$ jonirvruttikara Yoga ${ }^{20}$. As the patient was belonging to perimenopause age so this Yoga was prescribed to her considering the Rajonirvrutti. Other than that, many properties of these drugs worked on the main complaint of the patient which is as follows.

Haritki Churna administered to the patient is Tridoshahara but specifically is Vatashamaka ${ }^{21}$. Acharya Charaka mentioned it to have Doshaanulomana property and in Dhanavantri Nighantu specifically, Vataanulomana property has been mentioned that might had led to destruct the pathological variation of Vata Dosha which is the main cause in this case. Sroto-shodhana, Vatahara, Shothahara, Garbhashyashothahara, Anulomana, Vedanasthapana Karma ${ }^{22}$ of Haritki has been mentioned in classics which unitedly has led to purify the Srotas including Garbhashya and leading to Anulomana as well as physiological functioning of Vata specifically concerned with Garbhashya i.e. Apana Vata. Thus, physiological functioning of Vata along with Vedanasthapana property have led to pacify pain during menstruation. Anodyne action of Haritki $^{23}$ has been experimenting with that might have led to lessening pain by working at the level of sensory nerve impulses to the brain. Antispasmodic pharmacological activity ${ }^{24}$ has led to pacify pain by relieving spasms. Chebulagic acid present in Terminalia Chebula has been experimented to have COX-2 (Cyclooxygenase) inhibiting activity $^{25}$ The COX-2 enzyme is responsible for the synthesis of prostaglandins that are further responsible for dysmenorrhea ${ }^{26}$. So, COX-2 inhibiting property of Chebulagic Acid has led to inhibit the synthesis of prostaglandins and hence relieving pain during menstruation.

Amlaki Churna is also Tridoshashamaka and is Vatashamaka due to its Amla Rasa and Madhura Vipaka. ${ }^{27}$ It is having Anulomana property and is indicated in various Shoola ${ }^{28}$ like Shira Shoola and Parinamashoola indicating its Shoolaprashamana 
property that helped in pacifying pain during menstruation in this patient. Spasmolytic action of Amlaki $^{29}$ has worked on dysmenorrhea by inhibiting the factors causing spasm of the muscle of the uterus and thus destructing pathogenesis.

3. Saraaswatarishtha ${ }^{30}$ : Saraswatarishtha was given to the patient in quantity equal to water. Saraswatarishtha is a formulation consisting of many Dravyas that are having various properties that have led to the destruction of underlying pathology under this specific case. The main ingredients of this formulation are Brahmi, with other Dravyas like Shatavari, Vidarikanda, Haritki, Adraka, Mishi or Shatapushpa, Madhu, Dhataki, Harenu, Pippali, Vibhitaka, Guduchi etc. It has been indicated in a wide range of diseases out of which $R a$ jodosha is one of the indications that led to choosing this specific formulation for this particular case.

Its main ingredient i.e. Brahmi is Vatashamaka due to its Ushna Veerya which has led to Vata Shamana along with Anulomana due to its Anulomaka Guna. It is having Vedanasthapana and has been indicated in Kashtartava ${ }^{31}$ which was the predominant complaint of the patient in this case. Medhya Prabhava of Brahmi has also been assessed that have led to pacify the anxiety and tension related Psychosomatic entities concerned with dysmenorrhea. Brahmi is having various properties that have led to relieve dysmenorrhea in this case like it is having anodyne action, analgesic, anti-spasmodic and smooth muscle relaxant property ${ }^{32}$ Also, Medhya Prabhava might have led to balance the activity of the Autonomic nervous system thus balancing the activity of sympathetic nerves hence pacifying pain during menstruation.

Most other Dravyas of this formulation are mostly having Vedanasthapana, Shoolaprashmana, Anodyne, Anti-spasmodic, Analgesic properties like Shatavari $^{33}$ Shatapushpa $^{34}$ Haritki as mentioned earlier etc.

4. Panchtikta Ghrita Guggulu: This formulation contains several Dravyas mainly Nimba, Patola, Vasa, Guduchi, Kantkari, Guggulu and GoGhrita. It was prescribed considering its indication in Prabala Vata Roga ${ }^{35}$ and Vata vitiation being the main pathology in this patient. Most of the
Dravyas in it are having Vata-Shamana, Vedanasthapana, Shoolaprashmana Karma that have led to destruct the pathogenesis and, hence curing patients.

5. Tarunikusumara Churna, a polyherbal formulation containing Sanai, Taruni (Gulab), Triphala, Kali Maricha, Pippali, Tankana etc. was given considering its indication in Vivandha which was the associated complaint of the patient.

\section{CONCLUSION}

Endometriosis is a disease that can be understood as ectopic endometrium in with the functioning endometrium is present in the other sites rather than uterine mucosa presenting with a variety of symptoms ranging from asymptomatic to menstrual irregularity to infertility etc. If we consider in our Ayurveda, it can be corelated with Vatika Yonivyapda up to some extent based on similarity in symptoms. Incidences of Endometriosis is increasing day by day due to many reasons and Modern Medical Science has limited treatment modalities that range from hormonal therapies or finally the surgery (either conservative or definitive). So, Ayurveda has a great scope in this area of concern as a wide range of Ayurvedic Drugs are having the potential to treat the symptoms associated with endometriosis. In the present case study, whereby secondary dysmenorrhea (severe) due to endometriosis was treated with Dravyas like Rasna, Devdaru, Eranda, Haritki, Amalaki, Arjuna, Saraswatarishta having various Vata-Shamana, Vedanasthapana Karma and pharmacological actions same as that of drugs described for treating dysmenorrhea like Analgesics, Anti-Spasmodic were used and the patient was cured completely. So, from this study, we can conclude that above mentioned Ayurvedic medicines are effective in treating secondary dysmenorrhea due to endometriosis.

\section{REFERENCES}

1. Agnivesha, Charaka Samhita, Vidyotini Hindi Commentary, by Pandit Kashinath Shastri and Dr Gorakhnath Chaturvedi, Chaukhamba Bharati Academy, Reprint edition 2016, Part 2, Chikitsa Sthana, Chapter 30, Shloka no. 225-226 
2. Professor Premvati Tiwari, Ayurvediya Prasutitantra evum Stri Roga, Part I, Prasuti Tantra, Chaukhamba Orientalia, Reprint edition 2018, Pg. no. 64

3. Agnivesha, Charaka Samhita, Vidyotini Hindi Commentary, by Pandit Kashinath Shastri and Dr Gorakhnath Chaturvedi, Chaukhamba Bharati Academy, Reprint edition 2016, Part 2, Chikitsa Sthana, Chapter 30, Shloka no. 11

4. Professor Premvati Tiwari, Ayurvediya Prasutitantra evum Stri Roga, Part II, Stri Roga, Chaukhambda Orientalia, Reprint edition 2018, Part II, Pg. no. 64

5. Textbook of Gynaecology including Contraception, DC Dutta, edited by Hiralal Konar, Published by Jaypee Brothers, 7th edition 2016, Chapter 22. Pg. no. 248

6. https://www.who.int/news-room/fact-sheets/detail/endometriosis

7. https://en.wikipedia.org/wiki/Endometriosis_Society_of_India\#cite_note-DelhiMarch_28-2

8. Textbook of Gynaecology including Contraception, DC Dutta, edited by Hiralal Konar, Published by Jaypee Brothers, 7th edition 2016, Chapter 22. Pg. no. 250

9. Charaka Samhita, Sutra Sthana, Chapter 25, Shloka 40

10. Dravya Guna Vigyana, by Acharya Priya Vrata Sharma, Part 2, Audhvidha Aushadha Varga, Chaukhamba Bharti Academy, reprint edition 2012, Pg.no. 39

11. Anonyms, Database of medicinal plants used in Ayurveda CCRAS, Dept. of ISM and H, Ministry of Health and Family Welfare, Govt. of India, Reprint Edition 2008, Volume Pg. no.376

12. Anonyms, Database of medicinal plants used in Ayurveda CCRAS, Dept. of ISM and H, Ministry of Health and Family Welfare, Govt. of India, Reprint Edition 2008, Volume, Pg. no. 378

13. Dravya Guna Vigyana, by Acharya Priya Vrata Sharma, Part 2, Audhvidha Aushadha Varga, Chaukhamba Bharti Academy, reprint edition 2012, Pg.no. 60

14. Anonyms, Database of medicinal plants used in Ayurveda CCRAS, Dept. of ISM and H, Ministry of Health and Family Welfare, Govt. of India, Reprint Edition 2008, Volume, Pg.123

15. Anonyms, Database of medicinal plants used in Ayurveda CCRAS, Dept. of ISM and H, Ministry of Health and Family Welfare, Govt. of India, Reprint Edition 2008, Volume, Pg.125

16. Anonyms, Database of medicinal plants used in Ayurveda CCRAS, Dept. of ISM and H, Ministry of Health and Family Welfare, Govt. of India, Reprint Edition 2008, Volume, Pg.122

17. Dravya Guna Vigyana, by Acharya Priya Vrata Sharma, Part 2, Audhvidha Aushadha Varga, Chaukhamba Bharti Academy, reprint edition 2012, Pg.no. 71

18. Anonyms, Database of medicinal plants used in Ayurveda CCRAS, Dept. of ISM and H, Ministry of Health and Family Welfare, Govt. of India, Reprint Edition 2008, Volume, Pg. no.73

19. Anonyms, Database of medicinal plants used in Ayurveda CCRAS, Dept. of ISM and H, Ministry of Health and Family Welfare, Govt. of India, Reprint Edition 2008, se of Medicinal Planta, Volume, Pg. no.75

20. Bhaishjya Ratnavali of Shri Govind Das, Vidyotini Hindi Commentary, by Shri Kaviraj Ambikadatta Shastri, Editor Shri Rajeshwaradatta Shastri, Chaukhamba Prakashan, Varanasi, Reprint edition 2015, Chapter 67, Pg. no. 1042

21. Dravya Guna Vigyana, by Acharya Priya Vrata Sharma, Part 2, Audhvidha Aushadha Varga, Chaukhamba Bharti Academy, reprint edition 2012, Pg.no. 753

22. Anonyms, Database of medicinal plants used in Ayurveda CCRAS, Dept. of ISM and H, Ministry of Health and Family Welfare, Govt. of India, Reprint Edition 2008, Volume, Pg. no.283

23. Anonyms, Database of medicinal plants used in Ayurveda CCRAS, Dept. of ISM and H, Ministry of Health and Family Welfare, Govt. of India, Reprint Edition 2008, Volume, Pg. no.283

24. Anonyms, Database of medicinal plants used in Ayurveda CCRAS, Dept. of ISM and H, Ministry of Health and Family Welfare, Govt. of India, Reprint Edition 2008, Pg. no. 283

25. Bharat Kumar et.al, Chebulagic acid, a COX-LOX dual inhibitor isolated from the fruits of Terminalia Chebula Retz., induces apoptosis in COLO-205 cell line, Journal of Ethnopharmacology, Pubmed, June 2009

26. Textbook of Gynaecology including Contraception, DC Dutta, edited by Hiralal Konar, Published by Jaypee Brothers, 7th edition 2016, Pg. no. 147

27. Dravya Guna Vigyana, by Acharya Priya Vrata Sharma, Part 2, Audhvidha Aushadha Varga, Chaukhamba Bharti Academy, reprint edition 2012, Part II, Pg.no. 759 
28. Dravya Guna Vigyana, by Acharya Priya Vrata Sharma, Part 2, Audhvidha Aushadha Varga, Chaukhamba Bharti Academy, reprint edition 2012, Pg.no. 760

29. Anonyms, Database of medicinal plants used in Ayurveda CCRAS, Dept. of ISM and H, Ministry of Health and Family Welfare, Govt. of India, Reprint Edition 2008, Volume, Pg. no.283

30. Bhaishjya Ratnavali of Shri Govind Das, Vidyotini Hindi Commentary, by Shri Kaviraj Ambikadatta Shastri, Editor Shri Rajeshwaradatta Shastri, Chaukhamba Prakashan, Varanasi, Reprint edition 2015, Chapter 73, Pg. no. 1115

31. Anonyms, Database of medicinal plants used in Ayurveda CCRAS, Dept. of ISM and H, Ministry of Health and Family Welfare, Govt. of India, Reprint Edition 2008, Part I

32. Anonyms, Database of medicinal plants used in Ayurveda CCRAS, Dept. of ISM and H, Ministry of Health and Family Welfare, Govt. of India, Reprint Edition 2008, Volume Part I

33. Anonyms, Database of medicinal plants used in Ayurveda CCRAS, Dept. of ISM and H, Ministry of Health and Family Welfare, Govt. of India, Reprint Edition 2008, Volume I

34. Anonyms, Database of medicinal plants used in Ayurveda CCRAS, Dept. of ISM and H, Ministry of Health and Family Welfare, Govt. of India, Reprint Edition 2008, Volume 8, Pg. 357

35. Bhaishjya Ratnavali of Shri Govind Das, Vidyotini Hindi Commentary, by Shri Kaviraj Ambikadatta Shastri, Editor Shri Rajeshwaradatta Shastri, Chaukhamba Prakashan, Varanasi, Reprint edition 2015, Chapter 54, Pg. no. 904

\section{Source of Support: Nil \\ Conflict of Interest: None Declared}

How to cite this URL: Poonam Kumari et al: Effective Management Of Vatala Yonivyapda W.S.R Endometriosis By Ayurveda: A Case Report. International Ayurvedic Medical Journal \{online\} 2021 \{cited September 2021\} Available from: http://www.iamj.in/posts/images/upload/2271_2278.pdf 